\title{
Giant Cell Tumor of the Distal Radius Treated by Free Fibular Transfer
}

Essekkal M*, Admi M, Abdelkodouce J, Hassani I, Marzouki A and Boutayeb F

Department of Trauma and Orthopedic Surgery, A Hassan II Teaching Hospital, Faculty of Medicine and Pharmacy, Sidi Mohammed Ben Abdellah University Fez, Morocco
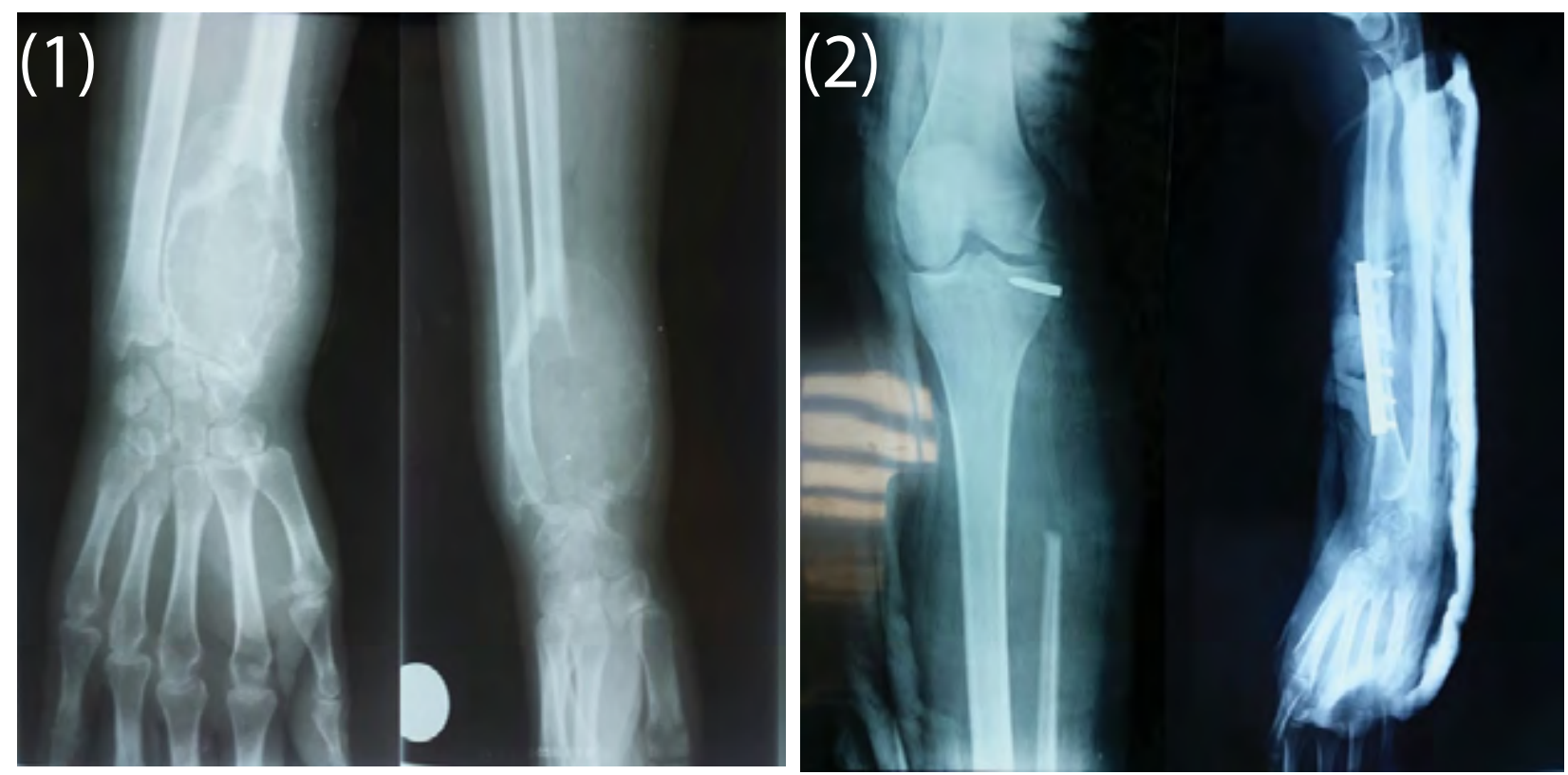

Figures 1: Standard radiography appearance showing an extensive and lytic epiphyso-metaphyseal tumor of the distal radius.

Figures 2: Standard radiography aspect showing the resection-reconstruction by a free fibular transfer and osteosynthesis by a screwed plate.

\section{Clinical Image}

The distal end of the radius is one of the sites commonly affected by giant cell tumor, It poses problems of reconstruction after resection of the distal radius.

We present the case of a 20 -year-old patient with a giant cell tumor grade 2 treated after resection by a free fibular transfer (Figures 1 and 2).

*Corresponding author: Essekkal Mohamed, Department of Trauma and Orthopedic Surgery A Hassan II Teaching Hospital, Faculty of Medicine and Pharmacy, Sidi Mohammed Ben Abdellah University Fez, Morocco, Tel: +212 5356-09660; E-mail: essekkalmohamed@gmail.com

Citation: Essekkal M, Admi M, Abdelkodouce J, Hassani I, Marzouki A et al.(2017) Giant Cell Tumor of the Distal Radius Treated by Free Fibular Transfer. Int J Clin Med Imaging 4: 564. doi:10.4172/2376-0249.1000564

Copyright: $\odot 2017$ Essekkal M, et al. This is an open-access article distributed under the terms of the Creative Commons Attribution License, which permits unrestricted use, distribution, and reproduction in any medium, provided the original author and source are credited. 